\title{
INSTITUTIONALIZATION OF ACCRUAL ACCOUNTING IN THE LOCAL GOVERNMENT OF MALANG
}

\author{
Wulandari Puspita, Unti Ludigdo, and Ali Djamhuri \\ Faculty of Economic and Business, Brawijaya University
}

\begin{abstract}
This study aims to understand the application of accrual accounting inthe Regency of Malang as public sector institution. This study using qualitative research with case study approach to understand the context of adopting accrual accounting in the Regency of Malang based on its organizational change using New Institutional Sociology's perspective. The results indicate that isomorphism occursduring theimplemention of accrual accounting in the government of Malang. The types are,coercive isomorphism through pressure from the central government using its regulation as the reason to adopt accrual accounting, mimetic isomorphism through learning from external parties that have more experience, and normative isomorphism through the role of professional actors. Decoupling behavior also emerges as a response to the changes in developing accrual based accounting standards.
\end{abstract}

Keywords:Accrual Accounting, New Institutional Sociology, Organizational change, Isomorphism

\section{INTRODUCTION}

Indonesia's reformation was the beginning for public sector management reformation in the country. Public wants the government to make changes by providing public services and reduces natural resources usage. Corruption and public distrusttoward the government have led to gaps in the society. The slope on the demand of Indonesian commodity in international market is also the reasons for the government to change its management. The changes were known as New Public Management (NPM). It is carried out by improving public sector management into accountingizationby adopting the management applied in private sector. Accountingization is a way to develop accountability using accounting as the method (Hood, 1995; Power, Laughing and Cooper, 2003). The use of accrual accounting is a apart of reformation in public sector management. It is objected to help public sector organizationsincrease their transparancy and accountability and improve their financial information into more effective and efficient one.

Based on NPM's philosophy,Indonesian government wants to improve the quality of their reports following the same pattern from other countries by applying accrual accounting. Learned from other countries experience for implementing accrual accounting such as Australia (Champoux, 2006), New Zealand (Champoux, 2006) and Nepal (AdhikariandMellemvik, 2011), the commitment of the goverment and the benefit of accrual accountingforce them to use the new accounting system.They must be supportedbygood quality of human resources, facilities and financing capabilities to successfully adopt new accounting system. Withoutthe supports, the implementation of accrual accounting would be hard to work.

The first step take by the government to reform their governmental accounting standard is byissuing Government Regulation No. 71 in 2010 (PP71) which regulates the use of accrual accounting in all governmental level. To provide maximum result in theadoption of the new regulation, the government mustinstitutionalize accrual accounting and make it as a part of their daily routineincluding the activities of local government in Indonesia. 
Local Government of the Regency of Malang (Pemkab Malang)uses Regional Government Budget (APBD) for their activities. Therefore, Pemkab Malang are obliged to makes financial statements regarding the APBD they use, and the statements should be based on the accounting standard. PP71requiresPemkab Malang to be responsible for the usage of accrual accounting for their financial statements. In 2013, Minister of Home Affairs Regulation (Permendagri)No. 64/2013helped local government, includingPemkab Malang,adopt accrual accountingwhich would be effective in 2015. Theregulations has encouraged them to apply accrual accounting immediately. Nevertheless, first, they have to be successful in implementing cash toward accrual accounting since it's considered easier than accrual. Finally in 2014, Pemkab Malang were awarded Modified Unqualified Opinion for their financial statement, allthough they still have to work better in adopting accrual accounting.

Regulation changes will lead to organizational to changes (Senior, 2002). To adopt accrual accounting, Pemkab Malang needs to changes their organization in order to reach compatibility with other organizations within the government. Times and money shoul be spent to institutionalize accrual accounting and to make it as a part of their daily routine. Based on organizational change model by Lewin (Robbins and Judge, 2008), if anorganization wants to change, it should overcomes pressures, resolve uncertainity, look for ways to change, and finally stabilize the change and make it as their new culture.

To examine the process ofadopting accrual accountingin Pemkab Malang, researcher used New Institutional Sociology (NIS) prespective. Qian and Burrit cited in Arroyo (2012) stated that NIS emphasizes in regulatory, normative, and cognitive elements that are considered as the pillars to undertand the change of their accounting management. Several researchers have published their research about public sector accounting; they are Mirna (2011) Harun and Kamase (2012); Normasyah, Kamil and Idawati (2015) Jantong (2016),and Citra (2016). They discussed about the way accounting encourage public sector organizations to change their practice. The changes can be applied properly if they can be institutionalized and have become a part of the organization's routine. To understand that, they used NIS as the analytical tool, and it is still quite relevant until now.

Each organization thatimplement accrual accounting haveits own way to develop it, includingchanging their organizational structure and behavior. In addition, organizational change is not enough when the changes have been made. The organization must maintain so it can be institutionalized and become a part of its daily routine. Therefore, the researcher is assured to observe theimplemention of accrual accounting in public sector, especially in Pemkab Malang. The question of this research is how the institutionalization process of accrual has been used in Pemkab Malang. The goal is to understand the institutionalization process of accrual accounting in Pemkab Malang.

\section{THEORETICAL FRAMEWORK}

This research uses New Institutional Sociology (NIS) to provide comprehensive conceptinexamining accrual accounting practices within an organization. Any organization in one environment will make changes in order to get legitimacy. Organizations have similarities in structure, behavior and activities even though they are developedin different ways (DiMaggio and Powell, 1983). In NIS, the similarity is called as institutional isomorphism. It occurswhen an organization is learning to act and behave from their environment. There are three mechanisms of institutional isomorphism namely coercive isomorphism, mimetic isomorphism, and normative isomorphism (DiMaggio and Powell, 1983). Coercive isomorphism is the result of either formal or informal pressures that occur in an organization because of itsdependencee on other organizations they perceive having similarities infunctions. 
Mimetic isomorphism refers to how an organization try to mimic others in terms of actions and structures because the mimicking organization believethat what they are doingwill give them some benefits. By mimicking other organizations, the legitimacy is expected to increase. Normativeisomophism is a part of professional demands that can be passed through formal education or through professional associations such as consultants, institutions, universities or seminars. Besides those three factors, an organization should pay attention to endogenous factors such as; human resources, behavior and language that support the organization's activities. In fact,formal structures can reduce efficiency and competitive feeling within an organization. That's why organizations need to maintain the harmony between formal structures and practices. Meyer and Rowan (1977) called it as decoupling which is creating and maintaining the gap between formal policies and actual practices.

To understand the process of how accrual accounting can be applied in organizational routine, Lewin's organizational change model (Robbins and Judge, 2008) is used. Lewin said that there are three stepsin organizational change. The first step is reducing resistance from individuals or groups (unfreezing). The second step is, changing the organization into the desired condition (moving) which is applying accrual accounting. And the third step is trying to stabilize the change until it becomes a new habit and can be institutionalized (refreezing).

\section{METHOD}

This research was conducted within a framework of qualitative research with case study as the background of the context of implementing accrual accounting using perspective of New Institutional Sociology. This study wants to see how an object in its natural condition without manipulating it. It uses case study approachin investigating a phenomenon in real life context. This approach is used especially when there are no boundaries and clearly defined context. This study usesdatatriangulation (Yin, 2009) since multiple data sources are used. The case study of this research emphasizes the interactive process of social construction using in depthdescription in performing the analysis. This method is more appropriate since this study only wants to know how institutionalization of accrual accounting takes place in Pemkab Malang. The researcher realizes that the application of accrual accounting needsto invole several processesbefore it can be institutionalized. To understand that process, thereseacher uses NIS as the analytical tool. Therefore, this research tries to disclose the technical aspectsof the implementation of accrual accounting, the reasons behind it, and its institutionalization process

The respondents were chosen based on their scope of work, availability and willingness to participate in each of targets. The respondents are officers ofPemkab Malang who where involved in the implemention of accrual accounting by their policy makers, administrators, as well as their internal auditor. The data of this study are from the response of the respondent's during interview, from the researcher's participation as passive observer, and from documents and public records. The interviews were conducted to obtain information based on the perceptions of the respondents regarding the implemetation of accrual accounting. They were held from January 2017 to February 2017, and were extended to June 2017. Most of the interviews were conducted individually, and the rest were carried in focus group discussion. The researcher used interview guide, so comprehensive information can be achieved. Passive observation was done to enssure that the interviewerswere involved in the implemention of accrual accounting and that the implementation was really taking place. Information from documents such as financial regulations, government regulations, articles and other financial documents are used to triangulate the findings from interviews and observations. 


\section{DISCUSSION}

The Regency of Malang (Kabupaten Malang) is one of the biggest regensiesin East Java. It covers the area of $3,534.86 \mathrm{~km}^{2}$. Its population is around 2,544,315 people spread in 33districts. In 2015, according to PP71,Pemkab Malang must use accrual accounting in their financial statements. It needs times and process to adopt accrual accounting since it is new for the administrators. Therefore, they need to change their organization in order to implement it.

Lewin said that, there are three steps of organizational change. The first step is reducing the resistance from individuals or groups. In doing so, Pemkab Malang have the commitment to prepare themselves to change and to adopt accrual accounting. At first Financial and Asset Management Board (BPKAD) were unable to apply accrual accounting in their work. The result of the interviewrevealed that there are people who felt that the new standard only make them do additional work and that it is difficult for them since they are used the their usual way of acconting process. Nevertheless, they were optimistic that they coulddoit since their superiors kept supporting them and always encouraged them to implement accrual accounting. Therefore, socializations about accrual accounting were conduscted to people in all management levels. The socializationhelps them understand the benefit and the importance of accrual accounting, not to mentionhelp Pemkab Malangreduceresistance factor.

The second step is, changing the organization into the desired condition, which is applying accrual accounting. Pemkab Malang made some strategies to implement the accrual.First, the improve their human resources by giving them some trainings based on the technical bulletin provided by the government. In BPKAD, theychoose people who have accounting background and who have experience in accounting department.Second, theychoose an application for their accounting information system to assist their accounting practices. They use Regional Management Information System (SIMDA), which is provided by Financial and Development Supervisory Board(BPKP). The used of SIMDA were based on their experience of using it. They choose the application also because of their trust toward BPKP. Third, theprovide regulation systems that can be used to guide them in accrual practices. This regulation was passedas Regional Regulation (Perbup) No. 12 in 2014 about accounting policies in Pemkab Malang and Perbup No. 13 in 2014 about accounting system in Pemkab Malang. These regulations are needed to support their activities in implementing accrual accounting and part of their commitment to implement the new system.

Human resources, SIMDA and regulations are the main instruments to prepare themselves for implementing accrual accounting. Furthermore, Pemkab Malang tried to improve their structure especially their assets systems by conducting census for their regional properties since assets become one of the important parts in accrual accounting. In addition, Pemkab Malang performed restatementson their financial statetements by making adjustments for accounts in their balance sheet.

The third step is trying to stabilize the change until it becomesa new habit and can be institutionalized. To encourage their officers to change their ways of thinking, BPKAD created some training activities that connectbetween accounting concept and accounting application system. This strategy is an effort to reflect their practical conduct and help them stay in their new comfort zone. Since accrual accounting is new for them, they faced some problems and obstacles during the practices. One of the causes is the low quality of human resources's in financial management and their low knowledge about accrual accounting. To overcome this problem, BPKAD actively helped other Regional Organization (OPD) find solutions for difficulties. When BPKAD cannot help solve the problems, they try to ask BPKP or to learn from others in forums, such as SIMDA's forum or public accountant's forum createdby the government.

Pemkab Malang tried to stabilize their accrual practicesby standardizing the condition in new regulation, so theirofficets do not try to return to the previous condition. They revised their 
accounting policy by issuingPerbup No. 36 in 2015 replacing their Perbup No. 12 in 2014 about accounting standard in Pemkab Malang. It's occured because there was an appeal from Audit Board of Indonesia (BPK)regarding discrepancies between their financial statement of 2015 and their regulation to include the financial reports of the previous year. In 2016, theyimproved their regulation by issuing Perbup No. 70, which replaced their regulation about accounting standard in Pemkab Malang,adjusting it with Permendagri No. 73 about allowance for receivables and allowance for revolving funds. Whenever there arenew regulations from the central government or suggestion from BPK, Pemkab Malang mustadjust their regional regulation as a part of their compliance to the government.

In 2016, Pemkab Malang tried to improve their internal control and change their organizational structure by splitting Department of Revenue, Finance and Asset Management (DPPKAD) into 2 parts as Regional Revenue Board (BPD) and Financial and Asset Management Board (BPKAD). The separation was done to comply with Regulation(UU) No. 23 in 2014, which mentions that income elements should not be combined with financial management because it can hinder their internal control which can potentionally being fraud.

Based onthe description, Pemkab Malang has their organization changed. It affects their behavior as part of accrual accounting implementation. Starts from making strategies for the implemention of accrual accounting and to the adoption process while implementing accrual accounting. In reality, the considerationfor using accrual accountingistrying to get legitimacy from government's environment, rather than the benefits ofimplemention. Pemkab Malang will have similarity in structures, behaviors, and activities with other local government units in that environment, although they have their own strategies in the process. In NIS that process is called as institutional isomorphism. There are three factors of institutional isomorphism, they are coercive isomorphism, mimetic isomorphism, and normative isomorphism. Next, this research will illustrate the institutional process of accrual accounting using the three factors.

The reason forPemkab Malang to implement accrual accounting is the existence of regulative pressure. Regulation(UU) No. 17 in 2003 requiresevery element of governmentto make financial statement using accounting standard.In 2010, the central government issued PP71 that requires the use of accrual accounting standards. The issuance ofPermendagri No. 64 in 2013 also encouraged the implementation of accrual accounting for local government. Theregulation can also be used as the basis for local regulations. Based onthe explanation above, coercive isomorphism appeared when institutional environment, which is Indonesia central government, set rules that forced their organizations to implement a new standard (Jonhston, 2013; DiMaggio and Powell, 1983). It is deduced that at the beginning, the need to adopt accrual accounting did not comefrom the desire of organizations to apply the new system, but it wasmore from external pressure in the form of PP71, so governments in all levelsmustobey that rules (Harun and Kamase, 2012). The regulation has the power to force all elements in thegovernmentto apply accrual accounting as part of their compliance.

Pemkab Malang made some preparations to implement accrual accounting, but they did not comprehend the adaptation of the accrual accounting process. Therefore, they tried to learn from other local governments that had already implemented accrual accounting. They choose to learn from PemkabBanyuwangi because they are one of the local governmentthat weresucceessful in implementing accrual accounting. Through learning from PemkabBanyuwangi, they knew how to support accrual accounting practices based on their commitment, system and how to work for their financial statements.

We can see that mimetic isomorphism occurs when an organization tries to imitates the actions by learning from other organizationsthat they considered as better and more successful institution(DiMaggio and Powell, 1983). Its happens when an organization has no goal to achieved or nocertainty offered. In addition imitating makes an organization feel more secure. 
This can be seen when Pemkab Malang must implement accrual accounting and they learned from PemkabBanyuwangi about accrual accounting. Mimetic isomorphism can also be seen when an organization indirectly uses other sources as their action model(DiMaggio and Powell, 1983). It can be seen through thePemkab Malang effort in solving their problems by finding out the solutions through accountant's forum or SIMDA's forum that manage by the government. Those forums help them learn from other organization's experiences that face the same problems or acquire some information about the new policies that should be applied.

To improve their human resources quality in implementing accrual accounting, Pemkab Malang asked BPKP to train their officers about the application accrual accounting and the use of SIMDA. In addition, when BPKAD cannot resolve the problems, they asked BPKP for the solution. At this point we can see that BPKP is a part of normative isomorphism when an organization involve the role of professional parties to establish norms and cultures in their organization (DiMaggio and Powell, 1983). There is another thing as part of normative isomorphism that have been done by Pemkab Malan. During their preparation for adopting accrual accounting, BPKAD moved officers with accounting background to their accounting departement.This is a part of personal screening, so both managers and officers can see the problems from the same prespective (DiMaggio and Powell, 1983).

Based on the explanation, it can be seen that coercive isomorphism is supported by mimetic isomorphism and normative isomorphism. When coercive power is indicated to adopt a certain behavior, the mimetic and normative have the power to make it happen by learning from other organization and using the help of professionals.

An organization consists of groups of individuals who have formal structures as well as ways of thinking and language to support their institutional activities. However, in the practices, those formal structures can reduce the efficiency and hinder competitive feeling withis the organization. Meyer and Rowan (1977) called that process with decoupling.

First, decoupling can be seen from the presence of professionals which is BPKP. The issuance of PP71 requires every all local governments including Pemkab Malang apply accrual accounting. However, limitations in human resources will only hamper the practices. To overcome the problems, BPKP plays its role by providing training and consultation for their local government officers.

According toPermendagri No. 64/2013, Pemkab Malang must adopt accrual accounting later in 2015. However, they could not commence the adoption since they are shortin human resources quality. It can be said that only them in BPKAD who are ready to adopt accrual accounting. To solve that problem, those in OPD were still record their transactions using cash toward accrual accounting. Meanwhile BPKADconduct their transactions by adjusting their financial statements into those that are in accordance with accrual accounting.

Decoupling can alsobe seen when Pemkab Malang used SIMDA so their transaction can be integrated quickly, but in practice they still need to strike and plug their data because their system has not fully connected especially the system between BPKAD and others OPDs. This happens because their location is quite separated and the budget for the project is low.

\section{CONCLUSIONS}

This research contributes to the understanding about accrual accounting in Pemkab Malang using three mechanisms of New Institutional Sociology. Pemkab Malang was forced to adopt accrual accounting because the coercive pressure of PP71. By implementing accrual accounting, Pemkab Malang would receivelegiticimacy from Indonesian central government. This coercive pressure also drovePemkab Malang to find models for accrual accounting implementation, in which they learned fromPemkabBanyuwangi, an organization that had succesfully adopted accrual accounting. In the process of adopting accrual accounting, they also 
learned from other organizations to solved the problems they faced, they were accountant forum or SIMDA forum managed by the central government. This signifies mimetic isomorphism in supporting the adoption of accrual accounting. In addition, professional support from BPKP shows the appearance of normative isomorphism in using and internalizing accrual accounting.

The role of BPKP is a form of decoupling. It is an effort to maintain the harmony between the formal form and the condition for adopting accrual accounting by provided knowledge for the officers ofPemkab Malang. Decoupling can also be seen when Pemkab Malang started to adopt accrual accounting in 2015. Since their officers do not know much about accrual accounting, they were more focused in producing financial statements based on accrual rather than starting from transaction. In addition, the practice of plugging and striking to connect the data for SIMDA wasdone due location distance and limited funds.

Based on this study, theresearchersuggestPemkab Malang to change their paradigm in applying accrual accouting, not for legitimacy but for improvement on the performance of the organization and for the benefit offered by the applucation accrual accounting. To successfully implementaccrual accounting, Pemkab Malang still need toimprove the qualitytheir of human resources, not only in BPKD but also in other OPDs by giving them more knowlegdeabout accrual accounting. Hiring more officers with accountingbackground is also advisable. Pemkab Malang can also maximalize their communication using the interner to synchronize their data or consult abouttheir problems. Similar researches for other public sector organization arestill needed since eachorganization hasits own characteristic in adopting accrual accounting. It is also necessary to have long term observations to see the impact and the benefit of accrual accounting in public sector organizations.

\section{REFERENCES}

Adhikari, Pawan and Mellemvik, Frode. 2011. The Rise and Fall of Accruals: a Case of Nepalese Central Government. Journal of Accounting in Emerging Economies. 1(2): 123-143.

Amirya, Mirna. 2011. Development of Budget and Accounting System of Brawijaya University Public Service Board. Tesis.Postgraduate Economics and Business Faculty of Brawijaya University.

Arroyo, Paulina. 2012. Management Accounting Change and Sustainability : an Institutional Approach. Journal of Accounting \& Organizational Change. 8(3): 286-309.

Champoux, Mark.2006. Accrual Accounting in New Zealand and Australia: Issues and Solutions. Harvard Law School Federal Budget Policy Seminar.

Citra. 2016. The Impact of Fiscal Decentralization, Performance Budgeting, and AccrualAccounting on Performance of Provincial Government of Gorontalo. Tesis.Postgraduate Economics and Business Faculty of Brawijaya University.

DiMaggio, P.J., and Powell, W.W. 1983. The Iron Cage Revisited: Institutional Isomorphism and Collective Rationality in Organizational Fields. American Sociological Review. 48(2): 147-160.

Government Regulation No. 71 in 2010 about Government Accounting Standards.

Harun, Harun and Kamase, Haryono.P. 2012. Accounting Change and Institutional Capacity: The Case of a ProvicialGovernmet in Indonesia. Australasian Accounting Business and Finance Journal. 6(2): 35-50.

Hood, Christopher. 1991. A Public Management for all seasons?.Public Administration. 69: 3-19. Hood, Christopher. 1995. The "New Public Management" in the 1980s: Variations on a Theme. Accounting, Organizations and Society. 20 (2): 93-109 
70 Institutionalization of Accrual Accounting In The Local.....

Jantong, Alfonsus. 2016. Factors Affecting the Readiness of Accrual-Based Governmental Accounting Standard Application (A Case Study in the Government Manggarai, East Nusa Tenggara). Tesis. Postgraduate Economics and Business Faculty of Brawijaya University.

Johnston, Mel. 2013. Mimetic, Coercive and Normative Influences and Decision of National Sport Organisation to Bid for World Championship Events. Auckland University of Technology. New Zealand.

Meyer, J. W., and Rowan, B. 1977.Institutionalized Organizations: Formal Structure as Myth and Ceremony.American Journal of Sociology. 83(2): 340-363.

Power, Michael, Laughing, Richard and Cooper, David J. 2003.Accounting and Critical Theory.Studying Management Critically.Sage Publications.132-156.

Regional Regulation of the Regency of Malang No. 12 in 2014 about Accounting Policies of Government of the Regency of Malang.

Regional Regulation of the Regency of Malangg No. 13 in 2014 about Accounting System of Government of the Regency of Malang.

Regional Regulation of the Regency of Malang No. 36 in 2015 about Accounting Policies of Government of the Regency of Malang.

Regional Regulation of the Regency of Malang No. 70 in 2016 about Accounting Policies of Government of the Regency of Malang.

Minister of Home Affairs Regulation No. 64 in 2013 about Accrual Accounting Implementation Standards at Local Government.

Regulation No. 17 in 2003 about Government Finances.

Robbins, Stephen P dan Judge, Timothy A. 2008.Organizational Behavior 2. 12th edition. Jakarta: SalembaEmbat.

Senior, Barbara. 2002. Organisational Change. Second edition. London: Pearson Education Limited.

Yin, Robert K. 2009.Case Study Research.Fourth Edition. London: Sage Publication. 